\title{
ResearchOnline@JCU
}

This is the Accepted Version of a paper published in the journal: Journal of Archaeological Science

Neri, Leee Anthony M., Pawlik, Alfred F., Reepmeyer, Christian, Mijares, Armand Salvador B., and Paz, Victor J. (2015) Mobility of early Islanders in the Philippines during the Terminal 1 Pleistocene/Early Holocene boundary: PXRF-analysis of obsidian artefacts. Journal of Archaeological Science, 61. pp. 149-157.

http://dx.doi.org/10.1016/j.jas.2015.05.005

(C) 2015. This manuscript version is made available under the CC-BY-NC-ND 4.0 license http://creativecommons.org/licenses/by-nc-nd/4.0/

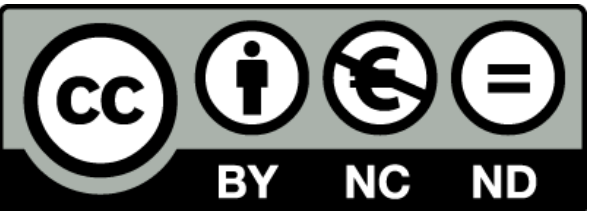


1 Title: Late Pleistocene/early Holocene maritime interaction in Southeastern Indonesia -

2 Timor Leste

3 Christian Reepmeyer ${ }^{1,2}$, Sue $\mathrm{O}^{\prime}$ Connor $^{2}$, Mahirta $^{3}$, Tim Maloney ${ }^{2}$, Shimona Kealy ${ }^{2}$

4

51 College of Arts, Society and Education, James Cook University, Cairns

62 Archaeology and Natural History, College of Asia and the Pacific, The Australian National

7 University, Canberra

83 Universitas Gadjah Mada, Yogyakarta

Abstract

This study analysed over 1000 obsidian stone artefacts excavated from two adjoining shelters on Alor Island Indonesia using portable XRF. The study showed an unambiguous separation of three different source locations (Groups 1, 2 and 3). Two sources (Group 2 and $3 a, b, c)$ dominate the assemblage numerically. Group 1 and 2 indicate use of a single volcanic formation with a strong match between Group 1 artefacts and artefacts from sites in Timor Leste. Obsidian occurs in the earliest occupation layer in the Alor sites but do not include Group 1 artefacts which occur only after approx. 12,000 cal BP. Currently the geographical location of the Group 1 outcrop is unknown, however based on the late appearance of the Group 1 artefacts in the Alor sequence it is likely that the location is not on Alor, but rather on another island of the Sunda chain. The dating of Group 1 artefacts in widely spaced sites on the never geographically connected islands of Timor and Alor indicates that maritime interaction between islands began by at least the terminal Pleistocene. The distribution of the obsidian in Tron Bon Lei shelter Pit B shows that there were periods of more intense interaction punctuated by periods when interaction declined or ceased. 
2 Identifying social interaction in prehistory is notoriously difficult, being based largely on

3 typological or stylistic comparison of different material expressions of assumed cultural identity (for example red-slipped pottery or flake-blade techno-complexes, Bellwood, 1997). Geochemically tracking the movement of raw materials provides the unique capability to cut through sometimes arbitrary archaeological classifications and provides direct evidence for maritime interaction if materials are sourced from off-island locations. Unfortunately, in Island Southeast Asia (ISEA), the data for correctly identifying off-island resource use is significantly under-researched as seen in a recent review paper suggesting that there are up to 10 additional, so far unknown, obsidian sources being utilised in Island Southeast Asia (Reepmeyer, et al., 2011b, Spriggs, et al., 2011).

Off-island resource use has important implications for the understanding of maritime capacity of hunter-gatherer societies. Until recently it has been assumed that seafaring technology during the Pleistocene and Early Holocene was simple and maritime interaction networks limited. In ISEA the assessment of maritime capability has changed in the last decade with evidence showing Upper Pleistocene hunter-gatherers ability for pelagic fishing (O'Connor, et al., 2011), increased social interaction between distant communities, including maritime transportation of raw materials being traced back to the terminal Pleistocene early Holocene transition (Bulbeck, 2008, Neri, et al., 2015, Pawlik, et al., 2015, Torrence and Swadling, 2008), and indications that a 'community of practice' existed in pre-Neolithic societies connecting islands in shared 'identities' (O'Connor, et al., forthcoming).

In this paper we present new data on two new obsidian sources in the Tron Bon Lei rockshelters on Alor Island (Samper Carro, et al., 2015). In addition, we will show that a further third obsidian source matches obsidian raw material utilised in Timor Leste (Reepmeyer, et al., 2011a). The new data provides additional evidence for maritime raw material transportation during the terminal Pleistocene / early Holocene transition, and it will be discussed whether sea-level rise during this time might be an important factor stimulating increased social interaction between island communities in the region.

\section{Site Context}


1 Today Alor has a land area of about $2100 \mathrm{~km}^{2}$. As one of the Wallacean islands, Alor has never been connected by a land bridge to Sunda (the enlarged southernmost extension of

3 Eurasia) or Sahul (Australia, New Guinea and the Aru Islands) or to the larger islands of

4 Timor or Flores (Kealy, et al., 2015). During the last lower sea stand, when sea levels were about 130 m below present, it was merged with neighbouring Pantar, Pura, Kambing, Rusa,

6 Ternate and Treweng islands; forming an island of about $3800 \mathrm{~km}^{2}$ (accounting for uplift of $\sim 0.5 \mathrm{~m} / \mathrm{ka}$ ) (Figure 1). It was at about this time that the Tron Bon Lei sites were first occupied (Samper Carro, et al., 2015).

[Figure 1]

Figure 1. Above: Location of the Tron Bon Lei rockshelter on Alor Island. Landmass extension during occupation history. Below: Location of research area.

Alor is largely volcanic in origin with a mountainous interior dropping steeply to a narrow coastal margin. The Tron Bon Lei shelters discussed here are formed in a ridgeline above the coastal village of Lerabain approximately $33 \mathrm{~m}$ above sea level and $160 \mathrm{~m}$ inland from today's seashore (Figure 2). The shelters are formed in fine-grained, dark to light grey, basaltic to andesitic volcanic deposits known as the Alor Formation which are of a presumed Late Miocene-Early Pliocene age (Noya, et al., 1997). The Alor Formation intersects with the calcareous Laka Formation and also contains volcanic breccias (Noya, et al., 1997), presenting as intercalated sub-angular to rounded clasts measuring up to $\sim 50 \mathrm{~cm}$ in diameter. Inside the shelter the floor consists of unconsolidated sediment with some large, fine-grained volcanic boulders on the surface that are of the same composition as those that can be seen in the shelter walls.

[Figure 2]

Figure 2: Plan view and section of the Tron Bon Lei rockshelter. Location of Pit A and B marked at the site. 
2 In 2014, three $1 \mathrm{~m}^{2}$ test pits were excavated in two adjoining shelters (Figure 2). Pit A was

3

4

5 excavated to $70 \mathrm{~cm}$ when bedrock was encountered. Pit B was extended to $3.2 \mathrm{~m}$ before reaching bedrock. Pit A presented challenges for dating as little organic material was preserved and only modern dates for the upper part of the sequence were obtained. Obsidian artefacts were scarce in the Pit A assemblage where only one piece of in total 59 samples was allocated to Group 1. Here we focus on Pit B which contains the majority of artefacts of Group 1 and has a clearly defined chrono-stratigraphic sequence. Thirteen stratigraphic layers were identified in Pit B, which included discrete well-defined stratigraphic features such as hearths and layers of flowstone (Figure 3, see also Samper Carro, et al., in press). Radiocarbon dating results for Pit B suggest three main phases of activity at the site: 1) late Holocene (ca. 3500 cal BP); 2) terminal Pleistocene-early Holocene (around 12,000 to 7500 cal BP); 3) late Pleistocene-Last Glacial Maximum (ca. 21,000 18,000 cal BP). The stratigraphy has been described in detail elsewhere (Samper Carro, et al., 2015). Here we focus on the changing distribution of obsidian sources within the sequence.

[Figure 3]

Figure 3: Section drawing of Pit B, Tron Bon Lei, with location of radiocarbon dates.

The upper excavation units (EUs) contained a small number of earthenware sherds. Aside from obsidian, stone artefacts were manufactured primarily from basalt $(43.6 \%$ of the assemblage) with small numbers of chert artefacts $(2.8 \%)$ also recovered. The faunal assemblage is dominated by fish (Samper Carro, et al., in press, Samper Carro, et al., 2015). The non-fish component comprises small quantities of marine turtle (Chelonioidea), small mammals, reptiles and birds. A detailed study of the fish bones from Tron Bon Lei has shown that as in neighbouring Timor Leste carnivorous species dominate in the Pleistocene and early Holocene levels and that an increase in smaller herbivorous/omnivorous reef fish 
occurs during the Holocene as sea level rose and coral reefs were established (O'Connor, et al., 2011, Samper Carro, et al., 2015).

\section{Methods and Results}

This sourcing study includes over 1000 obsidian stone artefacts excavated from two test pits in adjacent shelters in Tron Bon Lei Pit A $(n=59)$ and Pit B $(n=1005)$. Artefacts were selected by size and all artefacts larger than the threshold of covering the complete X-Ray beam ( $6 \mathrm{~mm}$ diameter) were analysed, 2998 artefacts were rejected based on size. The thickness of the artefact was disregarded, taking into account increased variability in the calculated elemental concentrations. The artefacts were geochemically analysed by portable X-Ray Fluorescence analysis (pXRF) with a Bruker Tracer III-SD. Manufacturer recommended settings of $40 \mathrm{keV}$ and $42 \mu \mathrm{A}$ were employed using a $0.1524 \mathrm{~mm} \mathrm{Cu}, 0.0254 \mathrm{~mm} \mathrm{Ti}$ and $0.3048 \mathrm{~mm}$ Al filter in the X-Ray path and a 60 second live-time count at $145 \mathrm{FWHM}$ setting. The raw counts of the pXRF were calibrated using 40 international standards provided by MURR (Glascock and Ferguson, 2012). Each artefact was analysed at two spots and the averages are presented here (Supplementary Table 1). Element concentration of manganese $(\mathrm{Mn})$, iron (Fe), thorium (Th), rubidium (Rb), strontium (Sr), yttrium (Y), zirconium ( $\mathrm{Zr}$ ) and niobium $(\mathrm{Nb})$ were calculated.

[Figure 4]

Figure 4: Principal component analysis of the Tron Bon Lei assemblage, + represent Group 1, $\square$ represent Group 2, • represent Group 3a, • represent Group 3b, represent Group 3c.

[Table 1]

Table 1: Summary statistics of pXRF analysis, averages represent absolute ppm counts (ANU9000 is an in-house reference standard, West New Britain - Kutau/Bao source).

The sourcing of the artefacts using Principal Component Analysis in the Past 3 freeware program (Hammer, et al., 2001) shows an unambiguous separation of three different source 
1 locations $^{1}$ (Figure 4). There is a linear spread of samples which indicates that the size of the artefacts increases variability in pXRF analyses (Ferguson, 2013, Lundblad, et al., 2008). Taking into account machine-induced geochemical variation, two source locations (Group 1 and Group 2) show a low-level of intra-source variability suggesting that artefacts provenanced to both source locations originate from single volcanic formations (Table 1). Group 3 obsidian artefacts present a slightly higher intra-source variability and it is possible that multiple outcrops of the same volcanic event were utilised (Figure 4: $3 a, 3 b, 3 c$, however there is a high potential that we only see the utilisation of one outcrop with higher variability in the geochemical signature). Group 3 artefacts can primarily be separated by discrepancies in Zr values (Group 3a: 220 ppm, SD 21.7; Group 3b: 185 ppm, SD 10.2; Group 3c: 134 ppm, SD 20.3), Group 3c with additional low Rb (78 ppm, SD 18.6) and Nb (8 ppm, SD 1.6) values. Group 2 has particular low Fe values (8370 ppm, SD 1238.6) and the geochemical signature of Group 1 shows an, for the region, unusual high Rb/Sr ratio (Rb 191 ppm SD 16.9, Sr 186 ppm SD 15.3; Average ratio 1.03).

[Figure 5]

Figure 5. Discriminant Function Analysis of Tron Bon Lei assemblage in relation to Island Southeast Asian and Western Pacific obsidian sources (data taken from pXRF analysis of ANU obsidian reference collection and SEM-EDXA and LA-ICP-MS data from Reepmeyer, et al., 2011b).

Artefacts from Alor were compared with the large reference database of Western Pacific and Island Southeast Asian obsidian sources (Reepmeyer, et al., 2011b, Summerhayes, 2009, Tykot and Chia, 1997). None of the identified groupings could be matched to any of the known sources in the region (Figure 5). The obsidian sources of the Western Pacific are relatively well understood (Reepmeyer, et al., 2016, Summerhayes, 2009), unfortunately, this is not the case for obsidian sources in Island Southeast Asia, where a recent study of $\sim 100$ artefacts was able to successfully source only $40 \%$ of the assemblages (Reepmeyer, et

\footnotetext{
${ }^{1}$ This indicates that the sources are geochemically sufficiently different from each other to be separated, taking into account that the samples don't meet minimum requirements for infinite thickness.
} 
al., 2011b). Widening the geochemical comparison database to include un-sourced artefacts from Island Southeast Asia and using Discriminant Function Analysis in PAST3, there is a strong match between Group 1 artefacts and artefacts from sites on Timor Leste (Ambrose, et al., 2009, Reepmeyer, et al., 2011a). Timor obsidian from several rock shelter sites (Buri Ceri Uato and Buri Ceri Uato Mane, Hatu Sour, Jerimalai, Laili, Matja Kuru 1 and 2) show the exploitation of one particular obsidian source recurrently (Figure 6). Our results suggest that it is highly likely that we are seeing the utilisation of this same obsidian source in the Tron Bon Lei site.

[Figure 6]

Figure 6. Discriminant Function Analysis of pXRF data comparing Tron Bon Lei artefacts with obsidian artefacts from the wider area. Ellipses represent 95\% confidence intervals from PCA groupings, red ellipse shows artefacts distribution of Timor Leste rockshelters.

In the larger Pit B assemblage Group 1 artefacts are relatively abundant. In total, 167 pieces in Pit B (16.4\% of the obsidian assemblage analysed) were allocated to Group 1 . The earliest occurrence of Group 1 artefacts in the stratigraphy is in Layer 11, EU 39-32, which has been dated to approx. 11,500 cal BP $(10,140 \pm 45$ bp (SANU 40125), an additional date of $10,230 \pm 30$ bp (SANU 41825) on an in situ fish hook confirms this age) ${ }^{2}$. A terminal Pleistocene-Holocene transition age for the initial use of Group 1 obsidian transportation into the site is confirmed by this.

[Figure 7]

Figure 7. Artefact and faunal assemblage distribution at Tron Bon Lei rockshelter.

Group 1 artefacts are not distributed equally throughout the stratigraphy (Figure 6). Separated by layer/EUs we can see a bimodal distribution with Group 1 artefacts being most

\footnotetext{
${ }^{2}$ For calibrated age-ranges, see Supplementary table 2
} 
abundant in Layer 10 (63 artefacts, 20\% of the assemblage) and a second peak in Layer 7 (25 artefacts, $43 \%$ of the assemblage). Layer 10 is bracketed by radiocarbon dates of $9340 \pm 35$ bp (ANU40128) and $8745 \pm 35$ bp (ANU39538). There appears to be a general lack of obsidian utilisation in Layer 9 (7355 \pm 35 bp (ANU39539) and 7250 25 bp (ANU40039)), Layer 8 shows only minimal use of Group 1 artefacts (15 artefacts, 7\% of the assemblage). Layer 7, which has the second peak in Group 1 obsidian utilisation, is bracketed by dates of $7060 \pm 30 \mathrm{bp}$ (ANU40121) in Layer 8 and $6620 \pm 30$ bp (ANU40123) in Layer 6. If we compare the distribution of Group 1 artefacts to the general utilisation pattern of obsidian sources at the Tron Bon Lei site, we see that only in Layer 10 do Group 1 utilisation peaks match use of all obsidian sources at the site. During the second peak of intense obsidian utilisation, in Layer 8, Group 1 artefacts were not abundant. Only slightly later, in Layer 7 after general utilisation of obsidian has peaked, we can see an increased use of Group 1 obsidian. Group 1 obsidian was then utilised in all later Layers 6 to 2 in small numbers. The distribution of Group 1 artefacts at TBL relates closely to the dates for the first inception of its use in rock shelter sites in Timor Leste. Although a single obsidian artefact from this source was located in the lower levels of Jerimalai dated to ca. 42,000 cal BP (Reepmeyer, et al., 2011a), the majority of the Timor Leste artefacts derive from levels dated after 14,000 cal BP, even in the case of sites such as Matju Kuru 2 (Langley and O'Connor, 2015) and Laili (O'Connor, et al., 2016) where initial occupation dates back to ca. 35,000 cal BP and 42,000 cal BP respectively.

Group 2 artefacts first appear in Layer 11 and from Layer 10 onwards Group 2 is the most abundant obsidian raw material throughout the stratigraphy, particularly during the two peak utilisation periods in Layer 10 and 8. Group 3 (all three sub-sources combined) artefacts occur in all layers of the site. They first appear in Layer 13 where they are the only obsidian source utilised and are most abundant in Layer 10 ( $n=128,40 \%$ of the assemblage) and 11 ( $n=114,65 \%$ of the assemblage). In tendency this source has been utilised more intensely in the earlier layers (Layer $13=100 \%$, Layer $12=88 \%$, Layer $11=65 \%$ ) and its abundance significantly decreases proportionally in later layers (Layer $6=29 \%$, Layer $3=$ $31 \%$, Layer $2=28 \%$ ).

Unfortunately, none of the raw material sources identified in the assemblage could be matched to a known obsidian source in the region, albeit some inferences can be made by 
the occurrence of Group 3 obsidians as the dominant source in the lower Layers and the later addition of Group 1 and 2 obsidians. We assume that Group 3 artefacts derive from a local source on Alor island, with Group 2 artefacts most likely also local. Supporting the assignation of Group 3 obsidian to a local source is the occurrence of small unworked nodules (in the form of small river-rounded pebbles, on average 10-20 mm in diameter) whose cortex matches cortex on some of the Group 3 artefacts. No unworked nodules were found which matched Group 1 or 2 artefacts.

\section{Discussion}

Recent research has shown that social interaction between distant communities, including maritime transportation of raw materials in ISEA, can be traced back to the terminal Pleistocene - early Holocene and it has been proposed that these changes might be associated with sea-level rise in post-LGM times (Bulbeck, 2008, Neri, et al., 2015, Pawlik, et al., 2015, Torrence and Swadling, 2008). Sea-levels during the Pleistocene/Holocene boundary at $11,000-12,000 \mathrm{cal}$ BP rose on average $12 \mathrm{~m} \mathrm{kyr}^{-1}$ (Grant, et al., 2012) and it has been argued that the loss of landmass from rising seas would have put established populations under pressure to adapt a more coastal and maritime focused economy (Barker and Richards, 2013, Soares, et al., 2008).

However, at Tron Bon Lei we are not able to see a change in maritime subsistence between the lower occupation layers dating to $18,000-20,000$ cal BP and the presumed initial maritime transportation of Group 1 obsidian (Samper Carro, et al., 2015). These findings echo recent results from sites in the Central Philippines (Neri, et al., 2015, Pawlik, et al., 2015), where the authors found no evidence for changing maritime exploitation patterns during this time period. On the other hand, Woodroffe et al. $(1988,2000)$ and Chappell (1993) have argued that rising sea levels would have indeed stimulated maritime migration and subsistence pursuits as sea-level rise creates more productive marine environments for human exploitation, such as reefs, localised back beach lagoons and estuaries, than the precipitous steep coastlines accompanying sea-level lows. This might seem to be particularly apposite in regions such as Timor and Alor where offshore profiles are steep.

Stable maritime exploitation patterns at the Tron Bon Lei rockshelter might be not surprising as the precipitous coastline during the time of sea-level rise did not change 
dramatically. The rockshelter today is $160 \mathrm{~m}$ distance to the shore in $33 \mathrm{~m}$ elevation, at the low point during the LGM it was not further than $2 \mathrm{~km}$ distance to the shore in $\sim 157 \mathrm{~m}$ elevation. Due to the steep offshore profile on the south coast of Alor and north coast of Timor the distance between Timor and Alor would have increased less than $0.5 \mathrm{~km}$ as sea levels rose to the mid Holocene high stand and thus there would have been little loss of land on these islands.

[Table 2]

Table 2: Abundances of obsidian artefacts in Tron Bon Lei and comparison sites in Timor Leste.

The pattern of first appearance of raw material transportation of obsidian from Group 1 during the time period of 12,000 to 10,000 cal BP is replicated in a number of rockshelter sites throughout the region. We compared raw material access of Group 1 obsidian at eight rockshelter sites in Timor Leste (Table 2, new data added for Laili and Hatu Sour added in Supplementary table 1) with the Tron Bon Lei site. In Jerimalai (Reepmeyer, et al., 2011a) shelter at the eastern end of Timor, a single obsidian artefact was recovered from the earliest level dated to around 42,000 cal BP. However most obsidian occurs in excavation units dating within the age-bracket 15,000-4000 cal BP, and an even later beginning of raw material usage at around 11,000 cal BP is likely (Supplementary Table 2, see also O'Connor, et al., 2011, Reepmeyer, et al., 2011a).

Matja Kuru 1 (MK1, Sq A and AA) and 2 (MK2, Sq D), are located to the west of Jerimalai, about $5 \mathrm{~km}$ from the coast and face south to the large freshwater lake, Ira Laloro. MK2 returned an age estimate of 35,500 cal BP for one of the lowest units, additional dates in associated excavation units confirmed this antiquity (Langley and O'Connor, 2015, O'Connor, et al., 2014). At MK2, 30 obsidian flakes were recovered occurring mostly in the Holocene, the earliest deposition of three flakes in EU 33 are bracketed by dates of $9205 \pm 55$ bp (NZA17001 in EU 32) and 9260 \pm 60 bp (OZG898 in EU35). MK2 appears to have little evidence of occupation before these dates and there appears to be a hiatus of occupation 


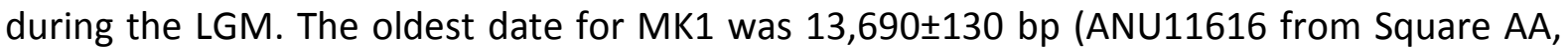
EU 21), but an inversion is evident in the age estimate of $9940 \pm 60$ bp (OZF-784 from EU25) $15-20 \mathrm{~cm}$ lower in the profile, and indicates some vertical disturbance. The second square, MK1 Sq A, only returned mid-Holocene dates, starting at 6000 cal BP (Langley and O'Connor, 2015, O'Connor, et al., 2014). Obsidian was found throughout the sequence in both excavation squares starting from the lowest units in MK1, Sq AA, with a single artefact in $\mathrm{EU}$ 25 , but most artefacts are associated with mid-Holocene layers.

Hatu Sour is a small cave on the central northern coast of Timor Leste near the modern village of Laleia. It has a Holocene sequence (Brockwell, et al., in press) with earliest occupation layers dated to $9650 \pm 45$ bp (ANU26609, in EU 35), EU 12 has a mid-Holocene date of $6165 \pm 25$ (ANU27105) and the uppermost layers returned a date of $315 \pm 25$ bp (ANU26606). Obsidian artefacts appear sometime prior to the mid-Holocene in EU 17 and continue through the sequence into the late Holocene.

At Laili, which dates to approx. 44,000 cal BP, Holocene deposits are not preserved (O'Connor, et al., 2016), but two obsidian flakes were found in EU 4 which dates to 11,000 15,000 cal BP (brackets are 12,789 \pm 47 bp (D-AMS 001649) in EU 5 and 10,295 \pm 43 bp (DAMS 007342) in EU 2). Bui Ceri Uato (BCU) and nearby Buri Ceri Uato Mane (BCUM) are on the Baucau Plateau. The Baucau sites are exceptional as they show the utilisation of multiple obsidian and local pitchstone sources in Timor Leste (Ambrose, et al., 2009, Glover, 1986). At $B C U$, local pitchstone use occurs from the lowest units (EU 30) associated with the initial occupation of the site at $11,000-12,000$ cal BP and cluster recurrently with another concentration in EU 21-20 (Glover, 1986). Group 1 obsidian was found in the second concentration in EU 20 and again in EU 7A. At BCUM, Group 1 obsidian occurs only from EU

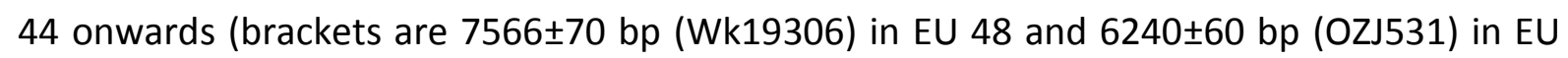
43) and EU 18 (2989 \pm 43 bp, OZJ527) (Olivera, 2008). No obsidian was found in uppermost layers dating to the late Holocene and there is an inversion with a mid-Holocene date in EU $16 \mathrm{~A}(5357 \pm 54 \mathrm{bp}, \mathrm{OZJ} 526)$, the excavators suggest that obsidian only occur in mid-Holocene layers dating between 7500 cal BP and 5500 cal BP (Ambrose, et al., 2009).

Clearly most of the evidence for obsidian use in the Timor Leste sites dates from about 14,000 cal BP or 12,000 cal BP onwards, even when sites have a much longer occupation record. The exception to this is Jerimalai where a single artefact is associated with units 
dated to $42,000 \mathrm{cal}$ BP (Reepmeyer, et al., 2011a). The stratigraphic contexts of the single obsidian flake in Jerimalai indicates that that there is a possibility of vertical displacement of the obsidian from higher in the profile. At Jerimalai an excavation unit less than $10 \mathrm{~cm}$ above the artefact was dated to post 14,000 cal BP (O'Connor, et al., 2011). With these exceptions Group 1 obsidian first appears just prior to the terminal Pleistocene after sealevel had already risen about $60 \mathrm{~m}$. Later usage of Group 1 obsidian during the second peak at Tron Bon Lei in mid-Holocene layers coincides with the mid-Holocene distribution of obsidian in sites such as BCU, BCUM and MK1 Sq A and AA. This might show a reintensification of interaction after a relatively short hiatus, when new sites are added to the network.

The pattern of separate systems regulating subsistence patterns and obsidian transportation is repeated in later layers where we can see a short-lived disappearance of Group 1 obsidian usage (Figure 6, Layer 9). This pattern cannot be explained through changing environment, we do not see a parallel drop in maritime resource exploitation (Figure 6), but it is reflected in a general drop of lithic artefact production/use at the site. Interestingly, we can see a proportional sharp increase in use of the Group 2 source in Layer 9 , however, this distribution is defined by very small artefact numbers.

Ambrose et al. (2009: 615) already noted the later date of initial raw material transportation in ISEA than in the Bismarck Archipelago where Mopir obsidian from West New Britain was transported to New Ireland by $20,000-18,000$ cal BP (Summerhayes and Allen, 1993). This remains the oldest evidence for inter-island transportation of obsidian raw material in the Indo-Pacific region. Initial obsidian exploitation of a local source for tool manufacture at Tron Bon Lei is dated to the LGM, which again is significantly later than in West New Britain, where obsidian flaked tools are associated with the earliest occupation layers at around 44,000 cal BP at Kupo Na Dari (Torrence, et al., 2004). This might indicate that Alor was not occupied prior to the LGM, which appears unlikely considering the Upper Pleistocene dates on Timor Leste. Similarly, it is unlikely that increased raw material transportation between Alor and Timor Leste sites, as well as between West New Britain and New Ireland (Summerhayes and Allen, 1993) and in the Central Philippines (Neri, et al., 2015), can been identified as indicative of the advent of advanced sailing technology. Distances involved in 
maritime transportation between these islands are fairly short ( $30 \mathrm{~km}$, up to $60 \mathrm{~km})$ and there is island-intervisibility across all sea gaps (Kealy, et al., 2015).

3 Alignment of coastal communities to maritime exploitation and sea crossing might be related to sea level rise as increased productivity in marine environments may have led to larger and more shell beds, the growth of reefs and estuaries in river deltas (Woodroffe, et al., 2000). These newly established environments might have been productive enough to allow population growth and stimulate intensified maritime subsistence pursuits. At the same time it is possible that increased precipitation and warming at the beginning of the Holocene made inland travel more difficult as rainforest increased (Burrows, et al., 2016, Reeves, et al., 2013) and areas which were previously more open vegetation became denser and likely more inhospitable to traverse. We see increased burning regimes of the direct post-LGM period (Haberle and Ledru, 2001) giving way to more humid environments which might necessitate increased human intervention to manage productivity. We can see intensified forest management strategies during this period in sites such as Niah cave on Sarawak (Barker, et al., 2011). Unfortunately, palaeo-vegetation data is scarce in our research area, so that we are unable to replicate this evidence, but there is no reason to assume that increased forest management was not also an adaptive necessity for huntergatherer communities in the South Wallacean islands. In this context, increased maritime connectivity might be an alternative or additional strategy to cope with changed environmental circumstances.

Imagery of boats is pervasive in the cultures of the Wallacean Islands (Ballard, et al., 2004). Houses and even entire villages are built to reference boats, and boats are a recurring motif in the rock art and later in the woven cloth made throughout the region. Even today on many of the smaller islands of the Lesser Sunda group movement between villages is heavily dependent on water transport as roads are few or non-existent and inland regions often mountainous and impassable. In this respect it is interesting to note that Group 1 obsidian, on the Alor coast and with widespread occurrence along the Timor Leste coast, does not occur at all in the inland sites of Uai Bobo 1 and 2 despite large lithic assemblage sizes (Glover, 1986). This could be viewed as a material reflection of social or familial networks maintained between coastal groups on adjacent islands communities and the lack of such networks between the coastal and inland communities in the same island. Although we do 
not yet know the source for the Group 1 obsidian, its presence in sites in both Timor Leste and Alor, from at least the terminal Pleistocene demonstrates the antiquity of maritime interaction in this region.

\section{Conclusion}

The application of pXRF to obsidian artefacts provides the opportunity to analyse large lithic assemblages in a relative short amount of time. Here we present the results of more than 1000 obsidian analyses from the Tron Bon Lei rock shelter on Alor Island. The data shows that three obsidian sources have been exploited, with all sources being separated unambiguously by pXRF geochemical finger-printing. There is the option of one source being sub-divided into three separate outcrops, but more data is necessary to confirm these results. None of the obsidian artefacts could successfully be sourced to any of the known sources in Island Southeast Asia or the Western Pacific.

The distribution of obsidian throughout the stratigraphy shows that initially most likely local sources were exploited in low numbers. The two other obsidian sources were added later, most likely not starting before the terminal Pleistocene. Two peak utilisations phases were identified with a short hiatus which is not equally reflected in the faunal assemblage. It is currently unclear why less lithic artefact deposition occurred in Layer 9 at the site.

The geochemical analysis showed that one obsidian source could be matched with obsidian artefacts in terminal Pleistocene sites on Timor Leste. However, it is probable that neither Timor Leste nor Alor were the locality for this source which is expected to be somewhere in the Sunda Arc. The appearance of the same source obsidian on both islands which were never connected via a land bridge, provides indisputable evidence for the maritime transportation of obsidian to these islands starting in the terminal Pleistocene. It has been suggested that sea-level rise may have provided the impetus for increased maritime interaction in the transition from the terminal Pleistocene to the early Holocene, however, the earliest transportation of obsidian raw material at the sites is not associated with evident changes in maritime resource use. An increased maritime subsistence focus may have led to social or familial links between islands, and resulted, over time, in the emergence of maritime interaction networks.

\section{Acknowledgements}


1 This research was funded through an ARC Laureate Fellowship to Professor Sue O'Connor 2 (FL120100156) and a Discovery Early Career Researcher Award (DECRA, DE130100046) to 3 Christian Reepmeyer.

4 


\section{References}

Ambrose, W.R., Allen, C., O'Connor, S., Spriggs, M., Oliveira, N.V., Reepmeyer, C., 2009. Possible obsidian sources for artefacts from Timor: narrowing the options using chemical data, Journal of Archaeological Science 36, 607-615.

Ballard, C., Bradley, R., Nordenborg Myhre, L., Wilson, M., 2004. The ship as symbol in the prehistory of Scandinavia and Southeast Asia, World Archaeology 35, 385-403, 10.1080/0043824042000185784.

Barker, G., Lloyd-Smith, L., Barton, H., Cole, F., Hunt, C., Piper, P., Rabett, R.J., Paz, V., Szabó, K., 2011. Foraging-farming transitions at the Niah Cave, Sarawak, Borneo, Antiquity 85, 492-509.

Barker, G., Richards, M.B., 2013. Foraging-Farming Transistions in Island Southeast Asia, Journal of Archaeological Method and Theory 20, 256-280.

Bellwood, P., 1997. Prehistory of the Indo-Malaysian Archipelago, University of Hawai'i Press, Honolulu, $\mathrm{HI}$.

Brockwell, C., O'Connor, S., Litster, M., Willan, R., in press. New insights into Holocene economies and environments of central East Timor: Analysis of the molluscan assemblage at the rockshelter site of Hatu Sour, NT Naturalist.

Bulbeck, D., 2008. An integrated perspective on the Austronesian diaspora: The switch from cereal agriculture to maritime foraging in the colonisation of Island Southeast Asia, Australian Archaeology 67, 31-51.

Burrows, M.A., Heijnis, H., Gadd, P., Haberle, S.G., 2016. A newlate Quaternary palaeohydrological record from the humid tropics of northeastern Australia, Palaeography, Palaeoclimatology, Palaeoecology 451, 164-182.

Chappell, J., 1993. Late Pleistocene Coasts and Human Migrations in the Austral Region, in: Spriggs, M., Yen, D.E., Ambrose, W.R., Jones, R., Thorne, A., Andrews, A. (Eds.), A community of culture: The People and Prehistory of the Pacific, Research School of Pacific Studies, The Australian National University, Canberra, pp. 43-48.

Ferguson, J.R., 2013. X-Ray fluorescence of obsidian: approaches to calibration and the analysis of small samples, in: Shugar, A.N., Mass, J.L. (Eds.), Handheld XRF for Art and Archaeology, Leuven University Press, Leuven, pp. 113-134.

Glascock, M.D., Ferguson, J.R., 2012. Report on the Analysis of Obsidian Source Samples by Multiple Analytical Methods, University of Missouri Research Reactor, Columbia.

Glover, I., 1986. Archaeology in East Timor, 1966-67, Department of Prehistory, Research School of Pacific Studies, Australian National University, Canberra.

Grant, K.M., Rohling, E.J., Bar-Matthews, M., Ayalon, A., Medina-Elizalde, M., Bronk Ramsey, C., Satow, C., Roberts, A.P., 2012. Rapid coupling between ice volume and polar temperature over the past 150,000 years, Nature 491, 744-747.

Haberle, S.G., Ledru, M.-P., 2001. Correlations among Charcoal Records of Fires from the Past 16,000 years in Indonesia, Papua New Guinea, and Central and South America, Quaternary Research 55, 97104. 
Hammer, $\varnothing .$, Harper, D.A.T., Ryan, P.D., 2001. PAST: Paleontological statistics software package for education and data analysis, Palaeontologia Electronica 4, 9-15.

Kealy, S., Louys, J., O'Connor, S., 2015. Islands Under the Sea: A Review of Early Modern Human Dispersal Routes and Migration Hypotheses Through Wallacea, The Journal of Island and Coastal Archaeology, 1-21, 10.1080/15564894.2015.1119218.

Langley, M., O'Connor, S., 2015. 6500-Year-old Nassarius shell appliqués in Timor-Leste: technological and use wear analyses, Journal of Archaeological Science xx, 1-18, http://dx.doi.org/10.1016/j.jas.2015.06.012.

Lundblad, S., Mills, P.R., Hon, K., 2008. Analysing archaeological basalt using non-destructive energydispersive X-Ray Fluorescence (EDXRF): Effects of post-depositional chemical weathering and sample size on analytical precision, Archaeometry 50, 1-11.

Neri, L.A.M., Pawlik, A.F., Reepmeyer, C., Mijares, A.S.B., Paz, V.J., 2015. Mobility of early islanders in the Philippines during the Terminal Pleistocene/Early Holocene boundary: pXRF-analysis of obsidian artefacts, Journal of Archaeological Science 61, 149-157.

Noya, Y., Burhan, G., Koesoemadinata, S., Mangga, S.A., 1997. Peta geologi lembar Alor dan Wetar Barat, Nusa Tenggara - Geological map of the Alor and West Wetar Quadrangle, Skala $1: 250.000$, Pusat Penelitian dan Pengembangan Geologi, Bandung.

O'Connor, S., Barham, A., Aplin, K., Maloney, T., 2016. Cave stratigraphies and cave breccias: Implications for sediment accumulation and removal models and interpreting the record of human occupation, Journal of Archaeological Science, xx, doi:10.1016/j.jas.2016.05.002.

O'Connor, S., Ono, R., Clarkson, C., 2011. Pelagic Fishing at 42,000 Years Before the Present and the Maritime Skills of Modern Humans, Science 334, 1117-1121.

O'Connor, S., Reepmeyer, C., Langley, M., Piotto, E., Mahirta, M., forthcoming. Communities of practice in a maritime world: shared shell technology and obsidian exchange in the Lesser Sunda islands group, in: Bellina, B., Blench, R., Galipaud, J.-C. (Eds.), Sea nomads of South-East Asia past and present, NUS Press, Singapore.

O'Connor, S., Robertson, G., Aplin, K.P., 2014. Are osseous artefacts a window to perishable material culture? Implications of an unusually complex bone tool from the Late Pleistocene of East Timor, Journal of Human Evolution 67, 108-119.

Olivera, N., 2008. Subsistence Archaeobotany: Food Production and the Agricultural Transition in East Timor, Archaeology and Natural History, The Australian National University, Canberra.

Pawlik, A.F., Piper, P., Wood, R.E., Lim, K.K.A., Faylona, M.G.P.G., Mijares, A.S.B., Porr, M., 2015. Shell tool technology in Island Southeast Asia: an early Middle Holocene Tridacna adze from Ilin Island, Mindoro, Philippines, Antiquity 89, 292-308.

Reepmeyer, C., Ambrose, W.R., Clark, G.R., 2016. Obsidian sourcing in the Pacific: New results using LA-ICPMS, in: Gratuze, B., Golitko, M., Dussubieux, L. (Eds.), Recent Advances in Laser Ablation ICPMS for Archaeology, Springer, New York.

Reepmeyer, C., O'Connor, S., Brockwell, C., 2011a. Long-term obsidian use at the Jerimalai rock shelter in East Timor, Archaeology in Oceania 45, 85-90. 
Reepmeyer, C., Spriggs, M., Anggraeni, Lape, P.V., Neri, L., Ronquillo, W.P., Simanjuntak, T., Summerhayes, G.R., Tanudirjo, D.A., Tiauzon, A., 2011b. Obsidian sources and distribution systems in Island Southeast Asia: New results and implications from geochemical research using LA-ICPMS, Journal of Archaeological Science 38, 2995-3005.

Reeves, J.M., Bostock, H.C., Ayliffe, L.K., Barrows, T.T., De Deckker, P., Devriendt, L.S., Dunbar, G.B., Drysdale, R.N., Fitzsimmons, K.E., Gagan, M.K., Griffiths, M.L., Haberle, S.G., Jansen, J.D., Krause, C., Lewis, S., McGregor, H.V., Mooneym, S.D., Moss, P., Nanson, G.C., Purcell, A., van der Kaars, S., 2013. Palaeoenvironmental change in tropical Australasia over the last 30,000 years e a synthesis by the OZ-INTIMATE group, Quaternary Science Reviews 74, 97-114.

Samper Carro, S.C., Louys, J., O'Connor, S., in press. Methodological considerations in the analysis of fish remains from archaeological assemblages: A case study from Tron Bon Lei shelter (Alor, Indonesia), in: Gabriel, S., E., R. (Eds.), Fishing through time: Archaeoichthyology, Biodiversity, Ecology, and Human Impact on Aquatic Environments.

Samper Carro, S.C., O'Connor, S., Louys, J., Hawkins, S., Mahirta, M., 2015. Human maritime subsistence strategies in the Lesser Sunda Islands during the terminal Pleistoceneeearly Holocene: New evidence from Alor, Indonesia, Quaternary International, 1-16.

Soares, P., Trejaut, J.A., Loo, J.-H., Hill, C., Mormina, M., Lee, C.-L., Chen, Y.-M., Hudjashov, G., Forster, P., Macaulay, V., Bulbeck, D., Oppenheimer, S.J., Lin, M., Richards, M.B., 2008. Climate Change and Postglacial Human Dispersals in Southeast Asia, Molecular Biology and Evolution 25, 1209-1218.

Spriggs, M., Reepmeyer, C., Anggraeni, Lape, P.V., Neri, L., Ronquillo, W.P., Simanjuntak, T., Summerhayes, G.R., Tanudirjo, D.A., Tiauzon, A., 2011. Obsidian sources and distribution systems in Island Southeast Asia: A review of previous research, Journal of Archaeological Science 38, 28732881.

Summerhayes, G.R., 2009. Obsidian network patterns in Melanesia - Sources, Characterisation and Distribution, Indo-Pacific Prehistory Association Bulletin 29, 109-124.

Summerhayes, G.R., Allen, J., 1993. The transport of Mopir obsidian to late Pleistocene New Ireland, Archaeology in Oceania 28, 144-148.

Torrence, R., Neall, V., Doelman, T., Rhodes, E., McKee, C., Davies, H., Bonetti, R., Guglielmetti, A., Manzoni, A., Oddone, M., Parr, J., Wallace, C., 2004. Pleistocene colonisation of the Bismarck Archipelago: new evidence from West New Britain, Archaeology in Oceania 39, 101-130.

Torrence, R., Swadling, P., 2008. Social networks and the spread of Lapita, Antiquity 82, 600-616.

Tykot, R.H., Chia, S., 1997. Long-distance obsidian trade in Indonesia, Materials Research Society Symposium Proceedings 462, 175-180.

Woodroffe, C.D., Chappell, J., Thom, B.G., 1988. Shell Middens in the Context of Estuarine Development, South Alligator River, NorthernTerritory, Archaeology in Oceania 23, 95-103.

Woodroffe, C.D., Kennedy, D.M., Hopley, D., Rasmussen, C.E., Smithers, S.G., 2000. Holocene reef growth in Torres Strait, Marine Geology 170, 331-346. 


$\begin{array}{lcccccccccccc} & n & & \text { MnKa1 } & \text { FeKa1 } & \text { ZnKa1 } & \text { GaKa1 } & \text { ThLa1 } & \text { RbKa1 } & \text { SrKa1 } & \text { YKa1 } & \text { ZrKa1 } & \text { NbKa1 } \\ \text { Group 1 } & 167 & \text { Av. } & 607 & 15270 & 79 & 25 & 25 & 191 & 186 & 43 & 192 & 20 \\ & & \text { SD } & 90 & 1846 & 13 & 3 & 3 & 17 & 15 & 3 & 11 & 2 \\ \text { Group 2 } & 410 & \text { Av. } & 816 & 8370 & 42 & 22 & 29 & 148 & 168 & 21 & 129 & 12 \\ & & \text { SD } & 123 & 1239 & 13 & 3 & 4 & 14 & 23 & 2 & 9 & 1 \\ \text { Group 3a } & 385 & \text { Av. } & 1118 & 48175 & 101 & 25 & 17 & 137 & 271 & 39 & 220 & 12 \\ & & \text { SD } & 125 & 5280 & 15 & 3 & 2 & 11 & 25 & 4 & 22 & 1 \\ \text { Group 3b } & 23 & \text { Av. } & 977 & 30959 & 72 & 25 & 23 & 153 & 233 & 32 & 185 & 13 \\ & & \text { SD } & 100 & 2961 & 10 & 3 & 2 & 9 & 16 & 3 & 10 & 1 \\ \text { Group 3c } & 20 & \text { Av. } & 1295 & 59766 & 108 & 24 & 9 & 78 & 342 & 26 & 134 & 8 \\ & & \text { SD } & 100 & 5625 & 24 & 2 & 3 & 19 & 30 & 2 & 20 & 2 \\ \text { ANU9000 } & & \text { Av. } & 475 & 8649 & 3 & 15 & 3 & 54 & 238 & 21 & 137 & 2 \\ \text { MURR-WNB1_05 } & \text { Pref. } & 592 & 8587 & 30 & 19 & 1.5 & 32 & 235.7 & 30 & 135 & 2\end{array}$


Click here to download high resolution image

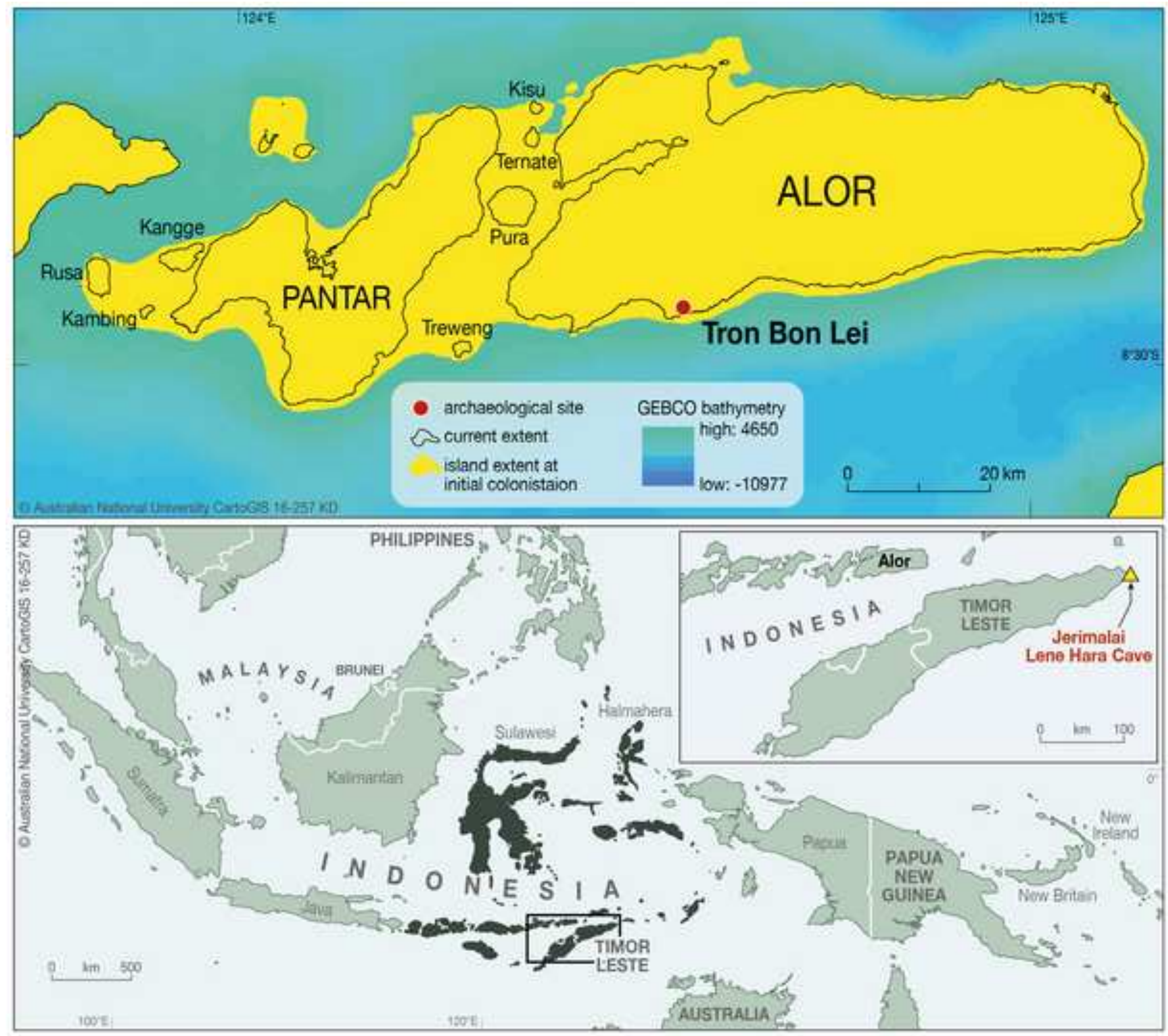




\section{Tron Bon Lei}

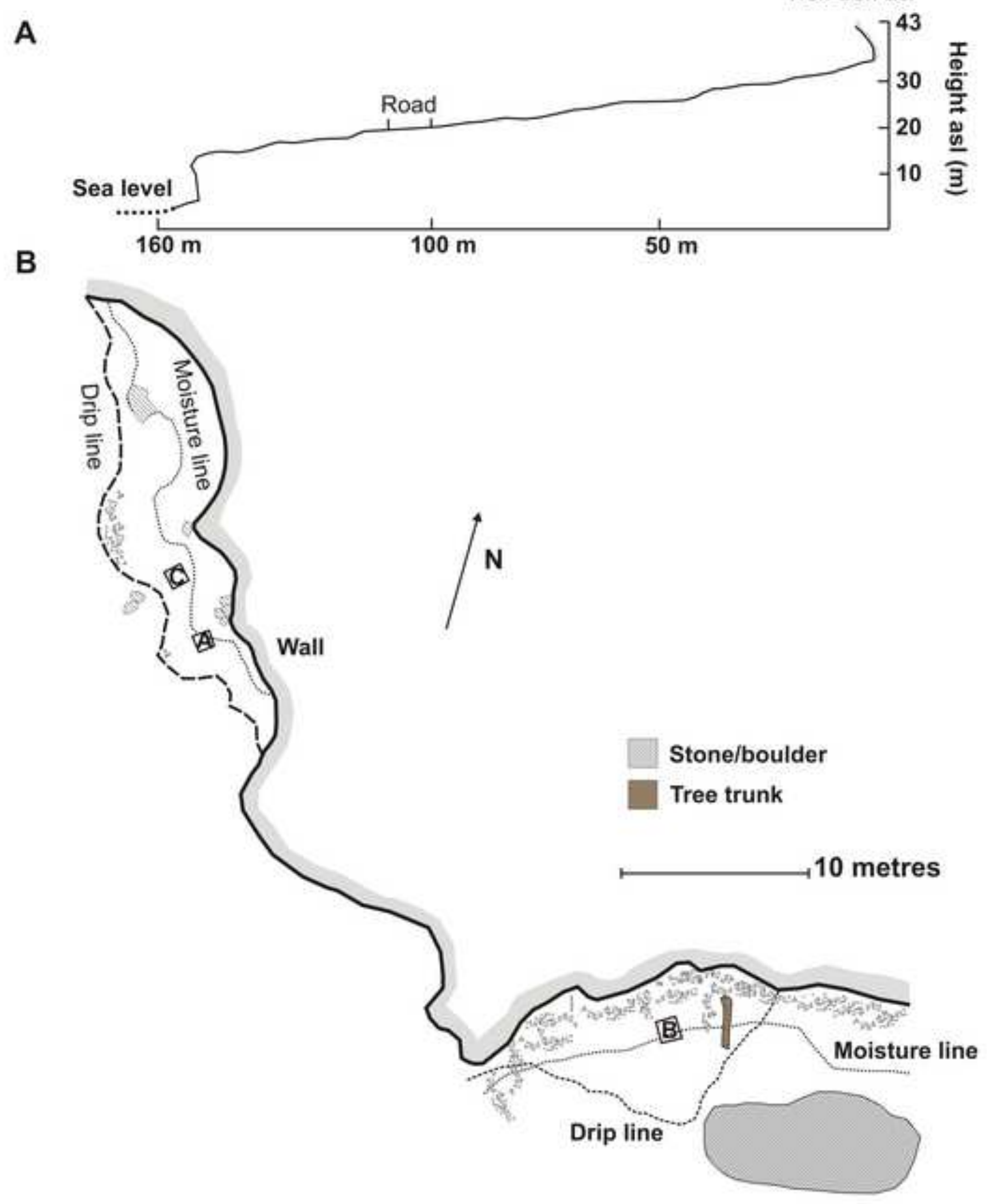




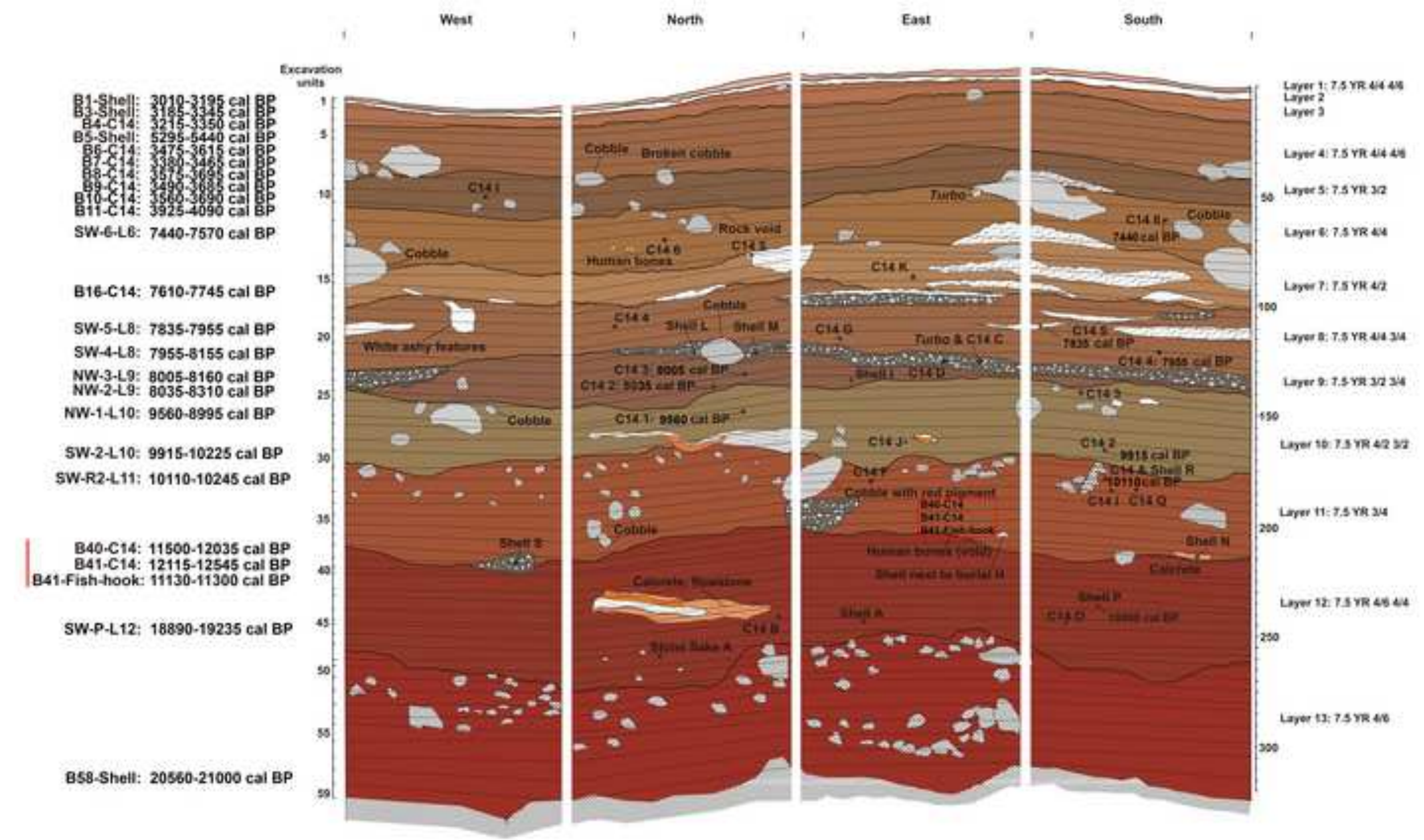

NW-3. $8005-8160$ cal ap NW-1-L10: $9860-8995$ cal BP

SW-2-L10: 9915-10225 cal BP SW-R2-L11: $10110-10245$ cal BP

W.P-L12: $18890-19235$ cal BP

858-Shetl: $20860-21000$ cal BP tareer 1: 75 YRe 4.440 Lamer

Loge 475 VRR 444 Lopers:7.5YR 3a uyere 7 stre at Legew 7:TSYK 42 Laper A: 7.5 YR 404 24 Loper 9: 7.5 Yh 373 is Lyyer 16,734842 as Laper $11: 7.5$ va 24.4 Wyer $12: 75$ VR 4584 230 
Click here to download high resolution image

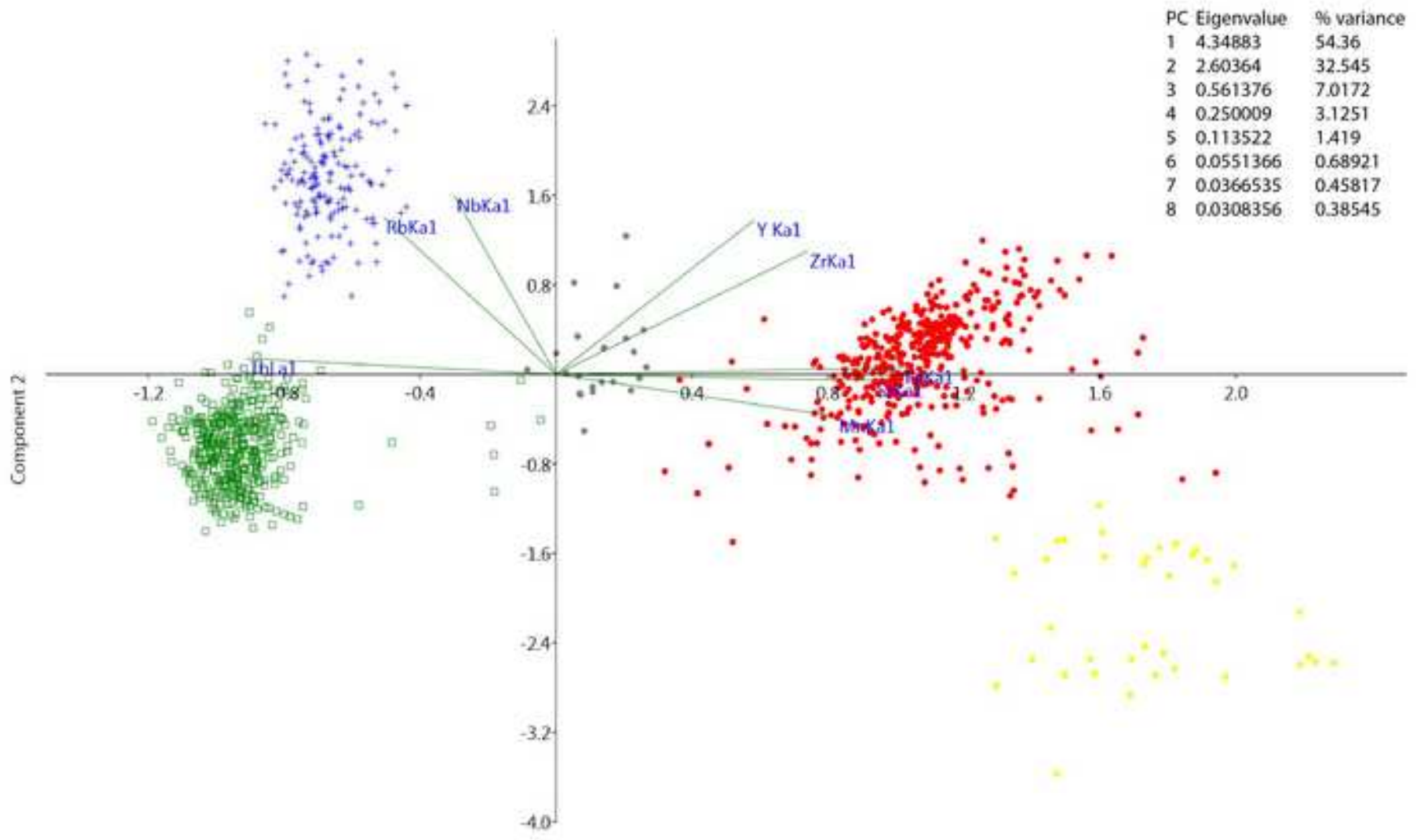

Component 1 
Click here to download high resolution image

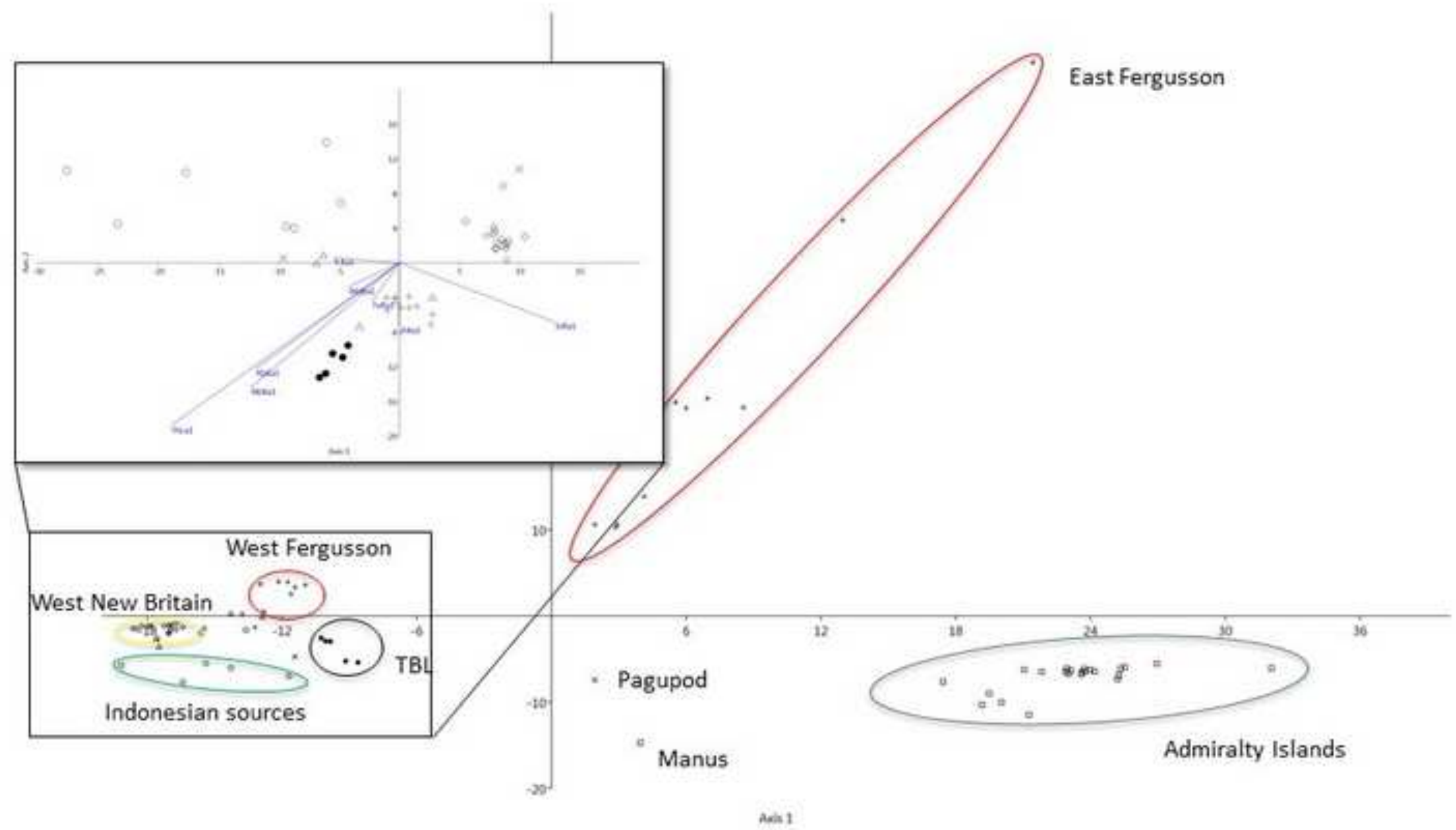


Click here to download high resolution image

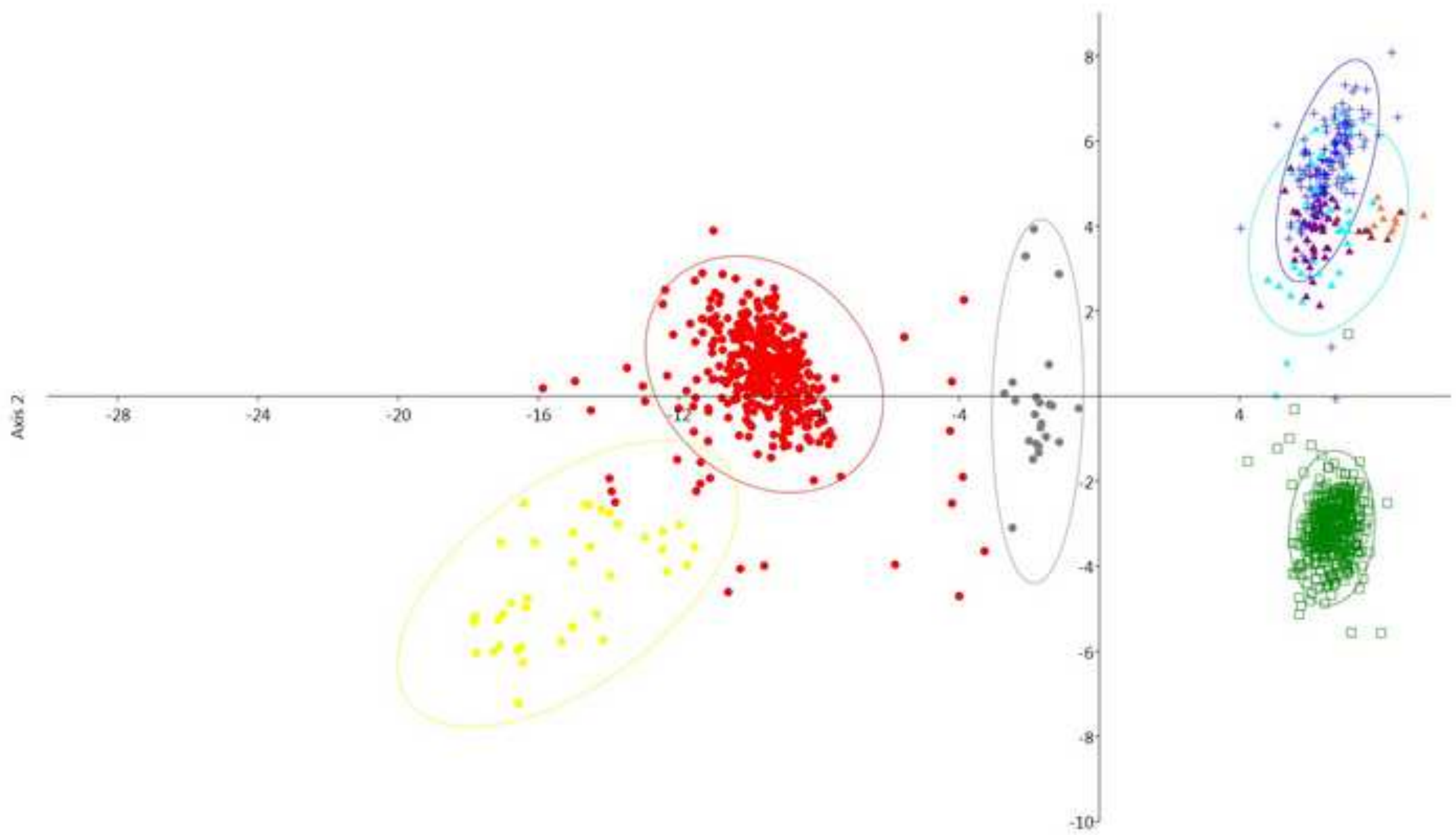

Anis 1 
Figure

Click here to download high resolution image

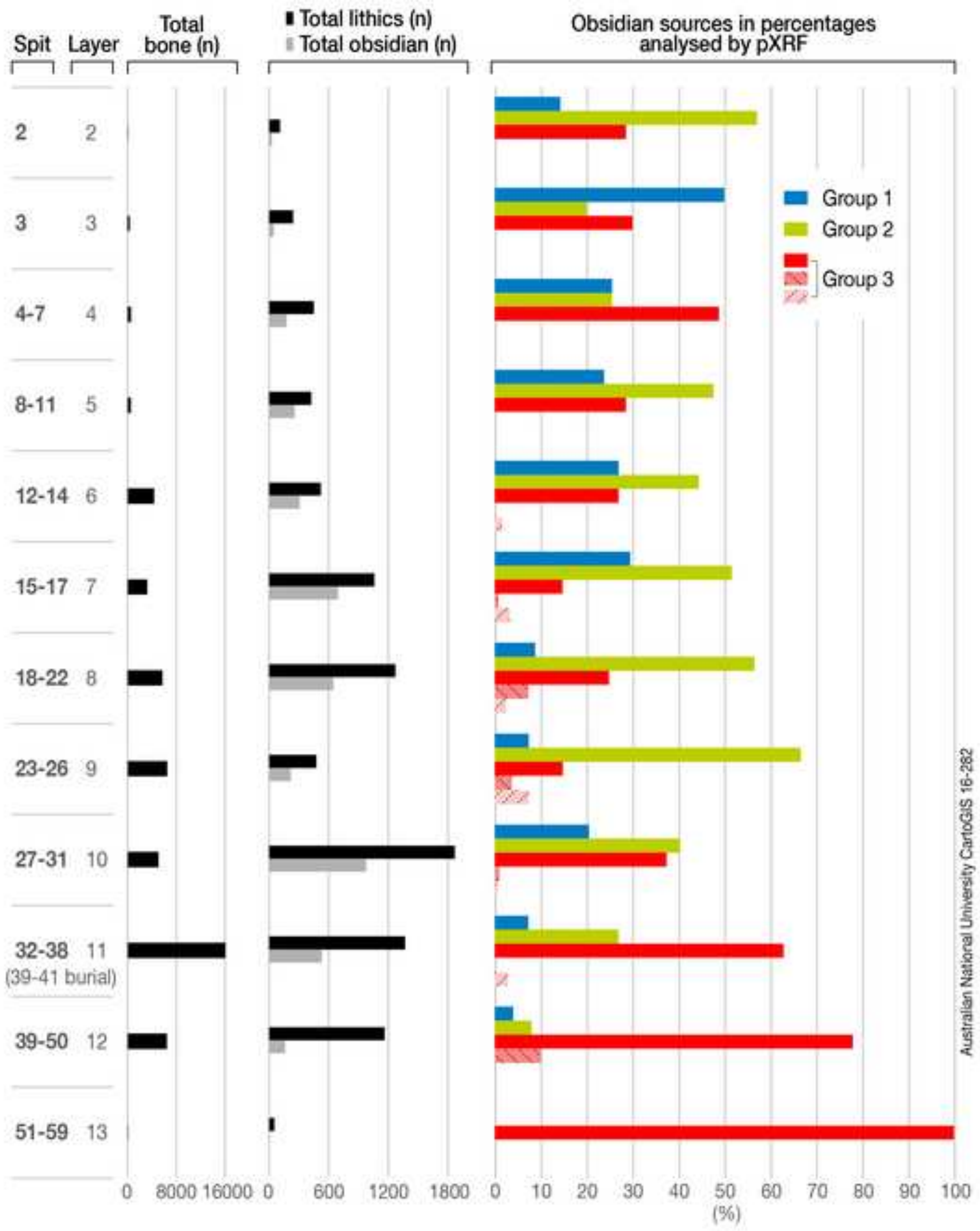


Supplementary Material
Click here to download Supplementary Material: Supplementary table - Summary pXRF data.csv

Supplementary Material
Click here to download Supplementary Material: Supplementary table - Summary pXRF data.csv

Clck here to download Supplementary Material: Supplementary table - Summary pXr data.csv

plementar

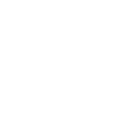

(1)

(1) (1) (1) (1) . . . . . . . . . . . . . . 
Supplementary Material

Click here to download Supplementary Material: Supplementary table - Summary table radio carbon.csv

作

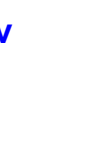

(1)

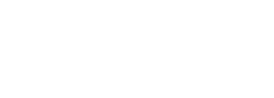
(1)

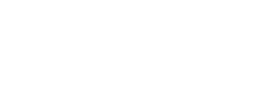
. . (1) (1) . . . . . . . . . . 列 